\title{
The Application of Sanitation and Hygiene Practice of Production Units to Enhance the Entrepreneurship Readiness to Produce Quality Food Products for Vocational High School Students of Culinary Program
}

\author{
Diana Evawati \\ Home Economics Education Department, Faculty of Teacher Training and Education, University of PGRI Adi Buana Surabaya Indonesia \\ *Corresponding author Email:diana@unipasby.ac.id
}

\begin{abstract}
The present study aimed at analyzing the application of the sanitation and hygiene in practical activities by the vocational high school production units in the catering service program as the competency of entrepreneurship readiness to produce food quality and safety. The study employed a qualitative method of research with a case study. The subjects of research included the school principal, head of the study program, head of the production unit, and the students. The data were collected through interviews, observation, and documentation and analyzed by using the interactive model of Miles and Huberman consisting of data reduction, data display, and conclusions. The results revealed that: (1) The application of sanitation and hygiene practices in the entrepreneurial activities required hands-on activities to engage students in real business activities in the production units; (2) the entrepreneurial competencies developed through the production units covered knowledge about entrepreneurship through self-knowledge and practical knowledge; mindsets of sanitation and hygiene including personal hygiene, environmental sanitation, health and safety, discipline, independence, creativity, communication skills, conceptual skills, decision-making skills, time management skills, and leadership skills. The application model of sanitation and hygiene practices in the entrepreneurial activities was developed through the production units. The evaluation and monitoring was conducted in two ways, by monitoring the performance and the products
\end{abstract}

Keywords: sanitation and hygiene, entrepreneurship readiness, production unit

\section{INTRODUCTION}

Entrepreneurship readiness can be defined as the ability and willingness of learners to prepare everything that is required when ones want to start entrepreneurship. Kris (2009: 4) states that before a person is self-employed, he must first have six capabilities: (1) the ability to formulate and manage the business purpose of life; (2) ability to motivate themselves; (3) the ability of the initiative; (4) the ability to form capital; (5) the ability to manage time; (6) the mental abilities based on religion; and (7) the ability to take lessons from the experience. Therefore, the students need to be equipped with various capabilities to be ready in entrepreneurship.

The production unit is a replica industry that is formed in vocational high school. The production unit is a business unit as the company in general. As a business unit of production units which must be managed as a company, because the production unit is a company formed in vocational high school. Type of business production unit set up to be something in common with the program developed in vocational skills which are relevant to consider the market potential in the area of the school environment. The production unit turns into the development model as well as the implementation of the company's business activities in schools.

The presence of creative industries provides opportunities for education managers to prepare students to be willing and able to compete in accordance with the demands of the market (Togar: 2011). Vocational graduates should have been prepared since they have been in school to get to know the competition of creative industries which are fraught with risk but the rewards are tremendous. The entrepreneurial spirit is already established in order to recognize and seize the opportunities that exist and not when the graduates enter the workforce. Graduates who tend to work in the formal sector are not because they are not capable of being entrepreneur but they do not get a chance to practice and compete in the field of creative industries. The majority of graduates want to work on others as employees or workers at the company for a regular wage or salary. It is a common debate that vocational graduates should dare to create jobs and not job hunting. 
Product development efforts on the activities of the production unit at secondary vocational school in catering is possible to provide students with the opportunity to capture market opportunities, develop creativity in developing products and compete in the creative industries. As it pertains to the human basic needs, business in the food and beverage sector can be regarded as lasting business. Therefore, restaurant and eateries businesses flourish like mushrooms in the rainy seasons. Culinary business development in Indonesia in recent years is even more massive. With a large population plus the number of middle class rose sharply, Indonesia becomes a more attractive potential market. Interestingly, not only the culinary industry market is dominated by small and medium sized players but some large companies even go jump in business. 'The players of culinary business in Indonesia are increasingly diverse, full and crowded'. As one of the sub- sectors of the creative economy, the culinary industry has the largest contribution to gross domestic product (GDP) sectors of the creative economy. Indeed, not all food and beverage services provider in the category of creative economy. In 2013, the value-added culinary industry reached IDR 208.63 trillion. The amount accounted for $32.5 \%$ of the total GDP of the creative economy sector which amounted to IDR 641.8 trillion.

Vocational high school in culinary program has major competencies in catering service and patisseries which support restaurants and hospitality program in vocational high school in tourism. Productive entrepreneurial model is expected to be more effective in the planting and cultivation of entrepreneurial spirit of independency in vocational high school in catering and tourism, so that the students are more independent and professional in all circumstances strive. Structuring their entrepreneurship curriculum that is integrated in the existing productive learning is expected to have more effective and efficient in a productive entrepreneurial model, cultivation of the soul, values and entrepreneurial behavior.

Sanitary food hygiene occupies an important position in support of food security of sanitation and hygiene. Sanitation includes clean way of working and septic in various fields, including the preparation, processing, preparation and transport of food, room cleanliness and sanitation of food processing tools and health of workers in the processing and presentation (Marriot Jenie 2000). The concept of personal hygiene in daily life is very important and must be considered as the concept of personal hygiene affects the health of a person. Cleanliness was greatly influenced by individual values and habits. Things are so influential that include cultural, social, family, education, a person's perception of health (Adams and Y. Motarjemi, 2003). At the time of serving food to customers or visitors, waitresses should pay attention to personal hygiene, cleanliness of clothes and equipment used must be in a good condition and clean, in order to avoid contamination of the food from dust, insects and bacteria. The increasing of public demand for foods provided outside home, the products provided by companies and individuals engaged in the business of providing food to the public interest (snack food), health and safety must be guaranteed. As one kind of public service that processes and presents, the food vendors have considerable potential to cause health problems or foodborne illnesses that result. Thus the quality of the food produced, presented and sold by food vendors must meet health requirements such as location factors and buildings, sanitation facilities, equipment, food processing.

Operation of catering to the concept of health has a prospective business opportunities based on the needs of modern society on the pattern of healthy food. At this time, the number of food service managers with the concept of health is still limited. This is because in starting and operating a business, food service managers are required not only able to manage only the culinary field. Managers must also understand the concept of health and nutrition related to preparation of a balanced nutritional composition based on the level of consumer needs. As a result, the level of the price offered is much higher than catering services in general.

Other potential markets for the organization of health food services are the existence of certain consumers who want a menu of special needs related to health programs. As for the health programs include a diet program for people with certain diseases, pregnant and lactating women, weight loss programs and other health programs such as vegetarian alternatives. The presence of a health food services helping consumers bring a combination of these in a healthy menu based on the benefits gained.Business development activities also greatly supported by the availability of human resources professionals that are adequate to support the activities of the management company. One human resource professionals in the catering activities, in health are nutrition experts. A nutrition expert is human resources professionals which are very important in supporting the process of organizing catering ranging from the booking process, menu planning process, production processes, up to the packaging process. The role of nutrition experts are not only limited to the daily activities of the management of catering health, but also plays a role in increasing the marketing efforts through consulting services for its customers.

Knowledge of food handlers about the hygiene of food sanitation is still lacking and low supervision and guidance of sanitation workers health to force food handlers at the restaurant. It can be found in Manado and Bitung, North Sulawesi, from a certain research showed that most food handlers in restaurants meadow have never been trained on hygiene. According Mukono (2000) all food processing activities should be protected from direct contact with the body. Protection of direct contact with the food the body can be done by wearing disposable gloves, use tongs food. To avoid contamination of food can be used apron, wearing hair's cap, and wearing special kitchen shoes and implement healthy behaviors in employees or other personnel during work with do not smoke, do not eat or chew, do not wear jewelry, always wash your hands before starting work and always wear work clothes or protective clothing properly. 
Organizing human resource, resources facilities, and management of teaching and learning activities of students are held so that the production units can support the implementation of the production unit program. The production unit is also an incorporated- entrepreneurs or a space of entrepreneur in school that have special authority of the head of the school to the manager to democratically perform its duties and responsibilities. Because the production unit is a space of entrepreneurship in school, then in its implementation should be managed to be developed in a growing space of entrepreneurship. Student involvement in the operation of the production units have not been implemented optimally. Student activities in the production unit was limited to handle the work of a practical nature, has not come to its management. This was confirmed by Widiarto (1997) states that the role of students in the activities of production units is still relatively small, limited to handle the work of a practical nature, and in terms of the numbers are still very little, which is about $2 \%$.

From these explanations, there is a gap between policy and its implementation of operational production unit as part of the implementation of sanitary hygiene in practical activities in production units in vocational catering services to create graduates who have entrepreneurial readiness and competence skills. From the results of presurvey research which had been conducted on 23 November 2015 to 27 November 2015 in three places, namely SMK Negeri 6 Surabaya, SMK Negeri 8 Surabaya and SMKK Matraman Bilis were found that the management of the production unit as one facility entrepreneurial learning showed inconsistency in hygiene in practical activities. Based on the pre survey completeness and supporting aspects of product units, SMK Negeri 6 Surabaya was chosen as the best among three vocational schools in Surabaya under the reasons of: 1) there is a production unit in courses catering services in schools that serve a practical experience for students; 2) implement a school production units of sanitary hygiene standard refers to the standard of expertise in catering; 3 ) production units of the school has been managing school resources to produce goods or services on a regular basis that will be sold for financial gain; 4) involve the students in its operations that can be a means of real training (on the job training) for students and teaching staff; and 5) there is a process of entrepreneurial learning in practical activities, namely the production unit with provision of venture capital to the students to entrepreneurship readiness after graduation from vocational school.

Research on the application of sanitary hygiene practices through the organization of production units in SMK Negeri 8 includes: 1) the conception of teachers on the application of sanitary hygiene to improve the quality of the safety of food products; 2) the readiness of entrepreneurial competencies developed in the practical activities of production units catering services; 3) entrepreneurial learning process through the activities of production units catering services that include strategy, implementation, and monitoring and evaluation.

\section{RESEARCH METHODS}

This study used a qualitative approach with a case study. According to Robert E. Stake (in Denzin\& Lincoln, 2009:299), the case study is not a methodology option, but rather as a selection of objects studied. Muhadjir (1996:38) explains that a case study is based on the accuracy of the researchers see the trends, patterns direction, the interaction of many factors, and other things that stimulate or inhibit change. This research was conducted at SMKNegeri 6 Surabaya. This selection is motivated by the completeness and reliability in the operation of the production units as a form of learning. The study has been conducted from December until March of the school year in $2015 / 2016$.

The subjects were in charge of the production unit, production unit manager, and executive production unit SMK Negeri 6 Surabaya. As a key informant to obtain data on the application of sanitary hygiene practice activities of production units and development competence is the head of SMK Negeri 6 Surabaya. In this study, the researchers collected data using interviews, observation, and documentation. The data analysis used in this research was Analysis Interactive Model of Miles and Huberman (1985:23) that divides the analysis activities into several parts: data collection, grouping according to variables, data reduction, data presentation, separating outlier data, and drawing conclusions or verification data.

\section{RESEARCH RESULT}

Teachers Conception of the Application on Sanitary Hygiene Practice Activities of Catering Production Unit

Vocational education should provide entrepreneurship education, as of its graduates who are directed to work in the industry, they are also prepared to be able to create new jobs in their fields through entrepreneurship. To form the student become an entrepreneur is not enough only equipped with the talent possessed by the students, but also students should have knowledge about all aspects of the business that will be practiced. Students can develop their talents through education at school. This also refuted the notion that entrepreneurship is an innate talent, so it cannot be learned and taught. Model and vocational education system must support to create a personnel readiness of new entrepreneurs through practical activities catering production unit. The application of sanitary hygiene are expected to improve product quality and food safety are able to compete in the area of product market competition catering services are worth selling, sharpening reasoning ability and entrepreneurial talent of students in order to create new job opportunities. This condition can be achieved when entrepreneurial education given to students is not just teaching theory, but also the direct application of that by involving students directly in real activity practice activities in the production unit. Awareness of the importance of entrepreneurship education has been recognized by educators at SMK Negeri 6 Surabaya. This is reflected in the learning 
process which has organized a production unit as one of the facilities of students in productive skills training and entrepreneurial skills with immediate application. According to Singh (1998:48) that the management of school business unit (unit of production) is effective in developing entrepreneurial skills to meet the needs of society and in the development of the goods or services that are tailored to the needs of the community. In addition, the presence of policies on the implementation of character education at every level, including vocational education has supported the planting of the values of entrepreneurship for students. The values of entrepreneurship is part of the basic values of character education that is as responsible, disciplined, hard working, creative, and independent. Those values can be integrated in the learning in each subject. Thus planting the values of entrepreneurship can be applied widely, not only applied to the subjects of entrepreneurship but also can be integrated in other subjects both groups of subjects normative, adaptive, and productive.

In fact, the school has made efforts to develop a curriculum to include the values of entrepreneurship education into the nation's character. Those values have been included in the curriculum in the form of hidden curriculum. But so far, these efforts have not been able to establish the student to become an entrepreneur, including the subjects of entrepreneurship theory. Therefore a real entrepreneurial learning activity is to involve students in the school production unit activities. Planting the values of entrepreneurship and the knowledge gained students in the subjects of normative, adaptive and productive will be applied significantly by students in learning activities in the production unit. So it can be said learning unit production is the outcome of entrepreneurial learning for students. Thus, learning the values of entrepreneurship is not only done on the cognitive level, but touched on the internalization, and real practice in the form of student involvement to manage the business in the production unit.In learning, the production unit had a short-term goal and long term goal. Short-term goal of learning the practical activities of production units as a source of school funding obtained from production gains, the profits are used for school operating costs. While the long-term goal to form students to become self-employee as an employer for himself and others with entrepreneurship.It is noticeable that despite the production unit is based learning business or profitability, but still emphasizes its education value, the process of learning for students in productive skills training and entrepreneurial skills.

\section{Developed Entrepreneurship Competence Readiness}

Entrepreneurial competencies that will be developed will serve as a foundation of the learning process and student assessment. Unfortunately, at this time developed entrepreneurial competence in learning in the production unit has not been contained and have not even conceptualized in lesson planning in the production unit. Although these competencies have not been conceptualized yet but the entrepreneurial learning process that is already running with the planting of the values of entrepreneurship was conducted by the teacher to the learner that leads to the development of entrepreneurial competencies. Researchers have identified the entrepreneurship readiness competencies developed by the school of learning in production units, the identification by interview, observation and documentation during the process of data collection in the field. Referring to the definition of competence expressed by Martinis (2005: 127) that competence is a basic capability that can be done by the students at the stage of knowledge, skills, and attitudes. Then, the entrepreneurial competencies are translated into three major groups, namely (1) knowledge, (2) attitude/behavior of the application of sanitary hygiene, and (3) skills of an entrepreneur.

First; entrepreneurial knowledge. From the research, in the process of practice in production units of SMK Negeri 6 Surabaya most teachers realize that the knowledge developed merely technical knowledge. This condition is similar to the statement of Gibb (in Fayolle, 2007:74) that in most of the formal education learning just concentrated on the transfer of explicit knowledge. While tacit knowledge that is not widely recognized by teachers, but this knowledge is crucial in shaping the character of an entrepreneur. However, the knowledge that is tacit knowledge has been taught or developed by teachers at teachingentrepreneurship through activities of production units, whether realized or not realized within the process of delivery. For example, when teachers assign work to students in managing the business group with the provision of capital to be developed, then in fact when the teacher has taught indirectly to the students that the money is seen as a resource, not the ultimate goal of business. Money or profits derived by the students will be managed proactively and used as a resource in developing its business continuously. Entrepreneurial knowledge developed includes self knowledge and practical knowledge. Self knowledge is knowledge that is tacit knowledge relating to knowledge of the type of business that will be executed and basic knowledge about entrepreneurship. While practical knowledge is knowledge that is explicit knowledge relating to practical knowledge such as knowledge of cooking techniques and manufacture, product quality control, accounting, and marketing.

Second; attitude behavior of the application of sanitary hygiene practice activities catering production unit. Attitudes/ behaviors applied include sanitary hygiene and safety, personal hygiene, environmental hygiene, discipline, and creative and innovative. Planting of these values is very important and has already started to be imparted to the students in learning entrepreneurship through activities of production units. This is considered important because of the general attitude / behavior of sanitation and hygiene is needed to maintain the continuity of entrepreneurship to ensure food safety to consumers, especially in running the business in the field of cookery.

Third; Readiness entrepreneurship. Equipped only with knowledge and entrepreneurial attitude are not enough if it 
is not equipped with the skills provision of expertise. Some entrepreneurial skills developed in entrepreneurial learning through activities Catering Production Unit of SMK Negeri 6 Surabaya include technical skills, human relations skills, conceptual skills, decision making skills, time management skill and leadership skills. In this case the productive skills or vocational skills in accordance with the competence of the expertise already included in technical skill, while the other is support skills.

\section{Entrepreneurship Learning Process Production Unit}

The assumption that entrepreneurship can be learned and taught as it can only be done through direct experience and had an inborn talent is a big one. Because the essential of entrepreneurship is a discipline that can be learned and taught. As well as the statement by Suryana (2009: 10) that entrepreneurship is a discipline that studies about the values, skills, and behavior in the face of life's challenges to pursue opportunities with the various risks that may be encountered. Therefore, elements of learning should be designed as well as possible in order to be able to create an entrepreneur in the field. In addition, the process of learning in entrepreneurship education should be directed to the real utilization of the knowledge and the ability to equip learners live in the midst of social life. It is a challenge for education to be able to design the learning process as well as with real experience (hands-on experiences), as stated by Hjorth (in Fayolle, 2007:50). And one way to do that is by involving students directly into concrete activities in entrepreneurship (by doing) or by way of apprenticeship (apprenticeship), as mentioned by Itkonen (in Stenström\&Tynjälä, 2009:160).

Entrepreneurial learning process, internalize or value investment of entrepreneurship to students in the activities of production units has been done by the teachers, but it is still not fully realized by many teachers that what they do are part of the process of entrepreneurial learning. Actually, the advent of the teacher unconscious is fueled by ignorance of teachers to the concept of entrepreneurial learning. In learning, the teachers pay attention more on the achievement of cognitive and psychomotor abilities aspects of entrepreneurial knowledge and skills of students as productive or vocational in cookery and forget about the achievement of the capability of attitude (affective). However, the cultivation of entrepreneurial attitudes is paramount to shape the character of an entrepreneur. How could someone be able to manage a business equipped with the knowledge and skills capabilities without having the ability in aspects such as creative and innovative attitude, independent, willing to take risks, and others. Target achievement entrepreneurial competencies of students who have not conceptualized in the activities of production units and the lack of awareness of teachers in the learning process of entrepreneurship through activities of production units due to the activity of production units is the teaching and learning activities outside the classroom that have not been formulated as an instructional objectives in learning and also this program apart from intracurricular activities. This has led to entrepreneurial learning through the production unit has not been conceptualized to mature.

\section{Learning Implementation Process Production Unit}

Implementation of entrepreneurial learning is done by the school through the activities of variety of production units catering services. It is done so that the entrepreneurial learning process is not monotonous and boring for students. The learning model used is to involve students directly in a real learning experience that managing a business in the field. It is very effective in directing students to achieve competence developed. As well as the statements from Carrier (in Fayolle, 2007:150) that the approach of experiential learning can support to acquire the skills, competencies, and an entrepreneurial attitude, besides it can also strengthen the integration of the acquisition of competency is more than just theoretical and technical knowledge. In the context of the students directly involved in four activities, namely knowing, thinking, doing, and participating.

\section{Monitoring and Evaluation}

Monitoring and evaluation should provide pedagogical benefits, namely in supporting learning systems (Singh, 1998:45). Monitoring and evaluation of the results can be used as reference for the next course, this is done in order to improve and enhance the quality of learning. In the implementation of the monitoring activities carried out by the production unit supervising teacher from the teacher productive. Each production unit is the perfect learning to shape entrepreneurial character, and even most developed competencies contained in the learning process. Students are taught in pioneering a group effort, ranging from preparing the business idea to the development. Therefore, as a prerequisite to follow this lesson,the students should have some basic competence which has been acquired by students during the class $\mathrm{X}$ entrepreneurial knowledge, skills, food processing, and food serving skills.

\section{CONCLUSIONS}

In applying sanitary hygiene practices production units catering to the readiness of entrepreneurship is not enough only equipped with the talent possessed by the students, but also students should have knowledge about all aspects of the business that will be practiced. To achieve this required entrepreneurial learning based on real experience that is by involving students directly into real entrepreneurial activities (hands-on experience), one of which is through the practice of entrepreneurial activities in the production unit.

Entrepreneurship readiness competencies developed in learning in production units, namely 1) the knowledge of entrepreneurship, includes: self knowledge and practical knowledge; 2) attitude/behavior of the application of sanitary hygiene, include: personal hygiene, environment, health, safety discipline, creative and innovative; 3) entrepreneurial skills, including: technical skills, human 
Procedia Food Science. Vol 65-67.

relations skills, conceptual skills, decision- making skills, time management skill, and leadership skill.

Implementation of entrepreneurial learning is done by the school through the activities of variety of production units catering services.It is done so that the entrepreneurial learning process is not monotonous and boring. In addition, the paradigm that developed among the teachers that the activity of production units is a learning activity that apart from activities that are not required intracurricular instructional design standard in learning as learning activities in the classroom. Moreover, monitoring the implementation of the learning is done in two ways: 1) performance monitoring); and 2) product monitoring. Meanwhile, efforts have been made to the evaluation of students' progress in participating in learning activities in which the production unit how to measure the profitability of product sales (profit-based evaluation).

\section{SUGGESTIONS}

1. It is expected to Surabaya City Health Department pro- actively provide education and facilitate to make easy of proceeding PIRTlicensingto support entrepreneurship readiness of catering services. Department of Education and Culture in Surabaya, in order to provide guidelines for the implementation in the management of entrepreneurial learning through the organization of the production unit at vocational schools and at the same time can provide capital assistance for vocational and entrepreneurship mentoring support the readiness of entrepreneurship.

2. SMK Surabaya provides a reference the implementation of sanitation and hygiene which can synchronize between subjects with learning reinforcement theory of entrepreneurship in the production units in order that the learning process has been linked to one another.

3. SMK is encouraged to continue to make breakthroughs on entrepreneurial learning by communicating to various stakeholders such as the Department of Education and Culture of East Java Province and the Department of Education and Culture in Surabaya as well as the business persons and the employers and others that a production unit can be a good source of entrepreneurial learning.

\section{REFERENCES}

[1] Adikari, Amarasekara (2016). "Food safety practices in a teaching hospital in Sri Langka". Procedia Food Science. Vol 65-67.

[2] Fraick, M., \& Gillian, N. (2012). "Peranan Orang Tua, Lingkungan dan Pembelajaran Kewirausahaan terhadap Kesiapan Berwirausaha". Pendidikan Vokasi, 15-26

[3] Adikari, Amarasekara (2016). "Food safety practices in a teaching hospital in Sri Langka".
[4] Costa, T. (2015). "Learning through experience and teaching strategies outside the classroom at design university studies". Journal Science Direct, pp 35-40 July 2014.

[5] Dorothy (2014). "Dietetics \& Food Service Manajement (MSCDFSM)". Turkish Online Journal of Distance Education (TOJDE), pp 350-358.

[6] Julie Carwile. (2009). "A case study of the selfdirected learning of women entrepreneurs". Virginia Commonwealth University

[7] Angelos J , Arens Johnson (2016) "Comparative Immunology , Microbiology and Infectious Diseases One Health in food safety and security education: A curricular framework". Journal Comporative Immunology, Microbiology and Infectious Diseases, 44, May 2016

[8] Rusnani. (2014). "Pelaksanaan Unit Produksi pada Sekolah Menengah Kejuruan Negeri Kelompok Pariwisata Jasa Boga". Jurnal Varia Pendidikan, 26 No 2.

[9] Jusoh, R. (2012). 'Effects of teacher' readiness in teaching and learning of enterpreneurship education in primary schools". Internasional Interdisclinary of Education, 1(Issue 7), 98-102.

[10] Cahyaningsih, 2011 Cahyaningsih, charini $T$. (2011)." Food Handlers Behavior and Methods of Washing Significantly Affect Bacteriological Quality of Eating Utensils at Foodstalls”. Jurnal Kesehatan Masyarakat, 25(4 desember), 180188.

[11] Barndt, D. (2013). "Blessings on the Food, Blessings on the Workers : Arts-based Education for Migrant Worker Justice". Canadian Journal of Environmental Education, 18, 59-79

[12] Blaauboer, 2016) Blaauboer. (2016). "Considering new methodologies in strategies for safety assessment of foods and food ingredients Margin of Exposure". Journal Food and Chemical Toxicology, 91, 19-35. .

[13] Diseye Juliet, O. (2013). "Survey on Employability Skills Among Post Graduate Students of Business Education in Edo State". European Journal of Educational Studies, 5(2), 197-207.

[14] Chairini, 2011 Chairini, C. (2012)."Food Handlers Behavior and Methods of Washing Significantly Affect Bacteriological Quality Eating Utensila Foodstalls". Berita Kedokteran Masyarakat, 25 desember 2016 180-188.

[15] Creswell, J. W. (2016). "Research Design". Yogyakarta: Pustaka Pelajar.

[16] Creswell, J. W. (2012). "Educational research: Planning, conducting, and evaluating quantitative and qualitative research". Educational Research (Vol. 4). 
experience by working in conjunction with completing their studies". Graduate Theses and Dissertations Iowa State University.

[31] Uyttendaele, M., Boeck, E. De, \& Jacxsens, L. (2015). "Challenges in food safety as part of food security: lessons learnt on food safety in a globalized world". Journal Procedia Social and Behavioral Science, pp 16-22.

[19] Benny, H. (2012). "When traditions become innovations and innovations become traditions in everyday food pedagogies". Australian Journal Adult Learning, 52(3),pp 595-616. April 2012

[20] Birdir K, P. TE. (2012). "Research chefs' competencies: A delphi approach. International Journal of Contemporary" Hospitality Management, 12,pp 205-212.

[21] Jusoh, R. (2012). "Effects of teacher' readiness in teaching and learning of enterpreneurship education in primary schools. Internasional Interdisclinary of Education", 1(Issue 7), 98102Karunasagar, 2016).

[22] Grabowska, B. S.-, \& Sukiennik, K. (2015). "Innovations in e-enterprises on the Polish market". Journal Procedia Social and Behavioral Science, 65(Iccmit), 1046-1051.

[23] Siswadi, Y. (2013). "Analisis FAktor Internal, Faktor Eksternal dan Pembelajaran Kewirausahaan yang Mempengaruhi Minat Mahasiswa dalam Berwirausaha”. Jurnal Manajemen Dan Bisnis, 13(1), 1-17.

[24] Joyce Kithure. (2016). 'Protective Health Education. Eurasian Journal Od Educational Reseach", 2(4), 35-36.

[25] Cornelia Reiher. (2012). "Food pedagogies in Japan: From the implementation of the Basic Law on Food Education to Fukushima Cornelia Reiher". Australian Journal Adult Learning, 52(3).

[26] Ko, W.-H., \& Chung, F.-M. (2015). "Learning satisfaction for culinary students: the effect of teaching quality and professional experience". International Journal of Vocational and Technical Education, 7(1), 1-13.

[27] Heidi M. Neck, P. G. G. (2013). "Teaching Entrepreneurship A Practice-Based Approach". The Journal International Social Research, $6((7)), 79-86$.

[28] Ruskovaara, E. (2014). "Entrepreneurship Education in Basic an Upper Secondary Education - Measurement and Empirical Evidence". Lappeenranta University of Technology.

[29] Rusnani. (2014). "Pelaksanaan Unit Produksi pada Sekolah Menengah Kejuruan Negeri Kelompok Pariwisata Jasa Boga". Jurnal Varia Pendidikan, 26 No 2.

[30] Schoffstall, D. G. (2013). "The benefits and challenges hospitality management students 